\title{
Evaluating Depression, Anxiety, Sexuality and Quality of Life in Metastatic Lung Cancer Patients
}

\section{Metastatik Akciğer Kanseri Hastalarında Depresyon, Anksiyete, Cinsellik ve Yaşam Kalitesinin Değerlendirilmesi}

\author{
Yelda Varol ${ }^{1}$, Umut Varol' ${ }^{2}$ Mustafa Değirmenci ${ }^{3}$, Gönül Pişkin ${ }^{3}$, \\ Nuri Aşık ${ }^{2}$, Murat Akyol', Tarık Salman' ${ }^{2}$ Utku Oflazoğlu' ${ }^{2}$, \\ Yüksel Küçükzeybek ${ }^{2}$, Ahmet Alacacıoğlu ${ }^{2}$, Mustafa Oktay Tarhan ${ }^{5}$
}

${ }^{1}$ Dr. Suat Seren Chest Diseases and Thoracic Surgery Training and Research Hospital, Department of Chest Diseases, Izmir, Turkey

${ }^{2}$ Katip Celebi University Ataturk Training and Research Hospital, Department of Medical Oncology, Izmir, Turkey

${ }^{3}$ Tepecik Training and Research Hospital, Department of Medical Oncology, Izmir, Turkey

${ }^{4}$ Manisa Government Hospital, Medical Oncology Clinic, Manisa, Turkey

${ }^{5}$ Institute of Oncology, Dokuz Eylul University, Izmir, Turkey

\section{ÖZET}

Amaç: Akciğer kanseri kısa yaşam beklentisi ve agresif tedavi seçenekleri nedeniyle hastaların hem yaşam kalitesini hem de psikoseksüel durumlarını etkilemektedir. Bu çalışmanın amacı akciğer kanseri hastalarında anksiyete, depresyon, cinsel doyum durumu ve yaşam kalitesinin değerlendirilmesidir.

Yöntemler: Birinci veya ikinci sıra kemoterapi alan metastatik akciğer kanseri hastalarıyla yüz yüze anketler yapılarak bilgiler toplanmıştır. Kullanılan anketler sosyodemografik karakteristikleri, Beck Depresyon Anketini (BDI), Golombok-Rust Cinsel Doyum Anketini (GRISS) and European Organization for Research on Treatment of Cancer Questionnaires-C30 Yaşam Kalitesi Anketini (EORTC-QoL-C30) içermektedir.

Bulgular: Bu çalışma 44 hastanın anket verilerini içermektedir. Hastaların anksiyete ve depresyon durumu için toplam Beck skoru çok yüksek çıkmıştır (sırasıyla; $15.60 \pm 12.30$ ve $16.02 \pm 11.39$ ). Metastatik akciğer kanseri hastalarımızın GRISS skorları anksiyete ve depresyon durumlarına göre değerlendirildiğinde herhangi bir istatistiksel anlamlılık bulunamamıştır. Hastalarımızdan anksiyete ve depresyon skorları yüksek olanlarda EORTC-QLQ-C30'un fiziksel, bilişsel, duygusal ve sosyal fonksiyonları istatistiksel olarak anlamlı şekilde düşük bulunmuştur. Rol fonksiyonu açısından sadece yüksek anksiyete skorlu hastalarda istatistiksel anlamlılık saptanmıştır.

Sonuç: Metastatik akciğer kanserli hastalarda yüksek anksiyete ve depresyon durumu, azalmış cinsel doyum ve bozulmuş yaşam kalitesi izlenmiştir.

Anahtar Kelimeler: Metastatik akciğer kanseri, depresyon, anksiyete, cinsellik, yaşam kalitesi

\begin{abstract}
Introduction: Lung cancer (LC) affects psychosexual outcome and quality of life (QoL) of the patients because of short survival period and aggressive treatment modalities. The aim of our study was to investigate anxiety, depression, QoL and sexual satisfaction levels of LC patients.

Methods: The data for metastatic LC patients treated with first or second-line chemotherapy were collected by using four forms completed during face-to-face interviews. The forms consist of socio-demographic characteristics, the Beck Depression Inventory (BDI), Golombok-Rust Inventory of Sexual Satisfaction (GRISS) and European Organization for Research on Treatment of Cancer Questionnaires Quality of Life-C30 (EORTCQoL-C30).

Results: Forty-four LC patients were participated in this study. The total Beck scores of patients for anxiety and depression were very high $(15.60 \pm 12.30$ and $16.02 \pm 11.39$; respectively). When we evaluated GRISS scores of our metastatic LC patients with respect to their anxiety or depression levels, we could not find any statistical significance. In the metastatic LC patients whose anxiety and depression scores were high, physical, cognitive, emotional and social functioning of EORTC-QLQ-C30 was found statistically significantly low. Statistical significance in terms of role functioning was only found in the patients with high anxiety scores.

Conclusion: Metastatic LC patients had high anxiety and depression levels, decreased sexual satisfaction and impaired QoL.

Keywords: Metastatic lung cancer, depression, anxiety, sexuality, quality of life
\end{abstract}




\section{Introduction}

Lung cancer (LC) is the most common cancer in the worldwide. Patients with lung tumors have a poor prognosis with $41 \%$ of patients surviving 1 year and only $15 \%$ surviving 5 years (1). The mechanisms through which lung cancer and its treatments affect patients' performance status and sexual desire are likely multifactorial; including physical, biological and psychological factors (2). Beyond the direct impact of lung cancer on patients, treatment itself may cause disstress, depression, anxiety and fear contributing to poor health outcomes. As a whole, because of the negative effects of cancer or its treatment, increasing quality of life (QoL) and emotional intimacy of these patients are very important (3).

Due to the decreased survival of LC patients, very few studies focused especially on sexual functioning during their treatment period $(4,5)$. So, little is known about the effects of lung cancer or chemotherapeutics on intimate and sexual relationships. Additionally, chemotherapy can cause several physical sexual problems, such as erectile dysfunction and ejaculatory failure, and emotional changes that affect lives of LC patients $(6,7)$. Alterations in physical appearance may also play an important role in sexuality of the patients with lung cancer receiving chemotherapy and influence their sexual identities. The impact of treatment with chemotherapy on appearance, self-esteem, and sexuality has been associated with decreased QoL and mental distress (8). Therefore, it is important to recognize the consequences of chemotherapy on sexual desire and counsel LC patients about their sexual activities are important aspects in providing comprehensive care.

Most of the lung cancer patients treated with chemotherapy have deterioration in QoL which is defined within five dimensions; physical well-being, material well-being, social well-being, emotional wellbeing, and, development and activity (9). However, physicians may sometimes ignore the importance of sexuality and social relationships for quality of life in LC patients. In this study, we aimed to examine anxiety, depression, changes in sexual functioning and QoL of the LC patients during their treatment period.

\section{Patients and Methods \\ Patient Selection}

Forty-four male metastatic LC patients with Eastern Cooperative Oncology Group performance status $0-1$ and who was having treatment for first or second-line chemotherapy in medical oncology clinics of Izmir Tepecik Training and Research Hospital, Izmir Katip Celebi University Atatürk Research and Training Hospital and Manisa Government Hospital between January 2015 and February 2016 were included in this study. Patients with poor performance status $(\mathrm{ECOG} \geq 2)$, old age $(>70)$ or receiving chemotherapy in the adjuvant stetting were excluded.A series of forms completed during face-to-face interviews by trained interviewers for determination of the sexual satisfaction, psychological status and quality of life of the patients were used. All of the participants were informed about the study and informed written consent was applied.

\section{Forms Completed}

In our study, there were four forms which were completed by the participants. In the first form, questions about the demographic characteristics of the patients were present.

Beck Depression Inventory (BDI) was the second form. It is composed of questions developed to measure the intensity, severity, and depth of depression in patients with psychiatric disorders. BDI included 21 questions or items, each with 4 possible responses. In order to indicate the severity of the symptom, each response is assigned a score ranging from zero to three. The questions of BDI assess mood, pessimism, sense of failure, self-dissatisfaction, guilt, punishment, selfdislike, self-accusation, suicidal ideas, crying, irritability, social withdrawal, body image, work difficulties, insomnia, fatigue, appetite, weight loss, bodily preoccupation, and loss of libido. BDI was translated into Turkish and its reliability was recalculated by Tegin and Hisli $(10,11)$. Items 1 to 13 assess symptoms that are psychological in nature, while items 14 to 21 assess more physical symptoms (12).

The third form was the Golombok-Rust Inventory of Sexual Satisfaction (GRISS). The 
GRISS is composed of 28-item questionnaire used to assess the presence and extent of sexual problems (13). It includes 12 subscales evaluating impotence, premature ejaculation, orgasmic disorder, vaginismus, lack of communication, avoidance in males and females, nonsensuality, insensitivity and dissatisfaction. In any category, a score of 5 points or higher indicates sexual dysfunction. A validation and reliability study of the GRISS in Turkish population was performed by Tugrul et al (14).

The fourth form was European Organization for Research on Treatment of Cancer Questionnaires Quality of Life-C3O (EORTC-QoL-C30). In this form, there are 30 items divided into three major domains that measure the quality of life of cancer patients: functional scales, global health/quality of life and symptom scales (15). Functional scales consist of physical (five items), social (two items), emotional (four items), role (two items) and cognitive (two items) items. Quality of life scale consists of two items. There are also nine symptom scales which were not included in our analysis (16).

\section{Statistical Analysis}

The data was analyzed by using SPSS for Windows version 20.0. A value of $\mathrm{p}<0.05$ was considered as significant. Descriptive statistics summarized frequencies and percentages for categorical variables, mean and standard deviation for continuous variables. For independent samples, T-tests were used to compare categorical variables.

\section{Results}

The median age of metastatic lung cancer survivors was 53.9 (range: 36-66). Thirty of 44 had received chemotherapy in the first-line while the rest had in the second-line treatment. About $6.8 \%$ of the LC patients had university educations. Thirty $\%$ of the lung cancer patients had members with cancer in their family before. Most of the patients $(86.4 \%)$ were smoker. Nearly almost all of the patients were married (95.5\%). Demographic variables of the patients were shown in Table 1 .

In the validation study of BDI in Turkey, the cut off value of anxiety is defined as $\geq 8$ and the cut off value of depression is defined as 10. The total Beck scores of lung cancer patients for anxiety were $15.60 \pm 12.30$ and for depression were $16.02 \pm 11.39$. In our study, the depression rate of LC patients was $68.2 \%$ (n:32) and anxiety rate was $75 \%$ (n:34) respectively.

When the patients' GRISS scores were evaluated with respect to their anxiety or depression levels, we could not find any statistical significance in our metastatic lung cancer patients. The mean GRISS scores of lung cancer patients were shown in Table 2. The mean GRISS scores of our patients according to their anxiety and depression levels were shown in Table 3.

Table 1: Socio-demographic variables of the patients

\begin{tabular}{lc}
\hline $\begin{array}{l}\text { Socio-demographic } \\
\text { Characteristics }\end{array}$ & $\begin{array}{c}\text { Patients } \\
(\mathbf{n}=\mathbf{4 4})\end{array}$ \\
\hline Age (mean \pm SS) (min-max) & $\begin{array}{c}53.9 \pm \\
\text { Education }\end{array}$ \\
$\quad$ Primary Education & $56(36-66)$ \\
High School & $36(81.8 \%)$ \\
University & $3(6.8 \%)$ \\
\hline Marital status & \\
Married & $42(95.5 \%)$ \\
Single & $2(4.5 \%)$ \\
\hline Cancer History of Family & \\
Yes & $13(29.5 \%)$ \\
No & $31(70.5 \%)$ \\
\hline Smoking History & \\
Yes & $38(86.4 \%)$ \\
No & $6(13.6 \%)$ \\
\hline Alcohol History & \\
Yes & $30(68.2 \%)$ \\
No & $14(31.8 \%)$ \\
\hline Lung Cancer Surgery & \\
Yes & $27(61.4 \%)$ \\
No & \\
\hline
\end{tabular}

In the metastatic lung cancer patients whose anxiety scores were high, physical, role, cognitive, emotional and social functioning subscores of EORTC-QLQ-C30 was found statistically significantly low. In the metastatic lung cancer patients whose depression scores were high, physical, cognitive, emotional and social functioning subscores of EORTC-QLQC30 were found statistically significantly low. There was not any significant difference in terms of global quality of life scores. The mean 
EORTC-QLQ-C30 scores of our patients were shown in Table 4. The mean EORTC-QLQC30 scores of our patients according to their anxiety and depression levels were shown in Table 5 .

\section{Discussion}

In our study, the depression and anxiety rates of our metastatic patients were very high $(68.2 \%, 75 \%$; respectively) and most of the patients had high psychological distress as expected. They were affected in terms of anxiety and depression mostly because of the

Table 2: The mean scores of Glombock-Rust Sexual Satisfaction of the patients

\section{Patient score}

\begin{tabular}{lc}
\hline Frequency & $5.08 \pm 1.78$ \\
Communication & $4.47 \pm 2.30$ \\
Satisfaction & $3.70 \pm 1.91$ \\
Avoidance & $5.65 \pm 1.03$ \\
Touch & $3.77 \pm 2.27$ \\
Premature Ejaculation & $5.02 \pm 1.67$ \\
Erectile Dysfunction & $6.0 \pm 1.12$ \\
\hline
\end{tabular}

short life-expentancy (17). Cataldo et al also found high anxiety, depression and symptom severity in metastatic lung cancer patients (18). In another study conducted by Haun, not only lung cancer patients but also their partners are prone to high levels of depression and anxiety or severe distress related to the poor prognosis of the illness (19). In advanced lung cancer patients, the changes of the severity of psychological distress was also investigated and moderate to severe depressive symptoms were found almost three times more common in the final 3 months of life (20). In addition to the chemotherapy duration, the place where cancer patients recieve chemotherapy may also be important. Delibegovic et al reported that when they treated the lung cancer patients at the Palliative Care Centre, they found that their high levels of anxiety and depression scores were significantly reduced and they represented a better way of treatment than treatment at home (3).

When we evaluated our patients' sexuality in terms of their depression and anxiety scores, we could not find any significant relation between the patients with low and high depression and anxiety scores. However, their GRISS scores were very high which means sexual dysfunction. This may be due to the psychological factors other than their mood disorders which may play an important role in sexuality of LC patients as well as their toxic treatments. Limited number of the studies was focused on sexual functioning during the treatment of patients with metastatic lung cancer. Because this was a cancer in which the mortality was too high. Besides, patients with lung cancer receiving chemotherapy can be affected by changes in appearance, self-esteem, and sexuality, and therefore may need sexual counseling (6). Lindau et al evaluated the communication about intimacy and sexual relationships for couples affected by lung cancer. They found that couples described negative effects which were driven by cancer or its treatment, including physical and psychological effects, and positive effects included an increase in non-coital physical closeness and appreciation of the spouse (4). Reese et al assessed the sexual concerns in patients with lung cancer and concluded that sexual concerns were common and stable, with $52 \%$ of patients reporting at least mild sexual concerns which were basically related to physical and emotional symptoms. They also found an association between age, gender and distress causing sexual symptoms in this population (5). In another study, researchers investigated changes in sexual functioning for lung cancer patients having treatment and determined baseline sexual function belownormal which was also worsened over time (7). According to this analysis, age was found to be a significant factor affecting sexual function.

Quality of life is usually associated with physical, phycological, sexual and social factors of cancer patients (21). We found that the presence of anxiety and depression in metastatic lung cancer patients deteriorated nearly all of these QoL functional scales 
except the global quality of life. For this reason, we have to consider rehabilitation of lung cancer patients in every stage of their disease. In a prospective study examining patients with advanced stage LC, depres-

Table 3. The mean GRISS scores according to anxiety and depression levels of the patients

$\begin{array}{llll}\text { Patient score } & \mathbf{P} & \text { Patient score } & \text { P }\end{array}$

\begin{tabular}{|c|c|c|c|c|c|}
\hline Frequency & & \multirow{3}{*}{0.734} & Frequency & & \multirow{3}{*}{0.126} \\
\hline Anxiety $\geq 8$ & $5.87 \pm 1.80$ & & Depression $\geq 10$ & $6.01 \pm 1.76$ & \\
\hline Anxiety $<8$ & $5.66 \pm 1.77$ & & Depression $<10$ & $5.21 \pm 1.71$ & \\
\hline Communication & & \multirow{3}{*}{0.803} & Communication & & \multirow{3}{*}{0.711} \\
\hline Anxiety $\geq 8$ & $4.53 \pm 2.27$ & & Depression $\geq 10$ & $4.56 \pm 2.11$ & \\
\hline Anxiety $<8$ & $4.33 \pm 2.49$ & & Depression $<10$ & $4.28 \pm 2.75$ & \\
\hline Satisfaction & & \multirow{3}{*}{0.190} & Satisfaction & & \multirow{3}{*}{0.186} \\
\hline Anxiety $\geq 8$ & $3.93 \pm 2.06$ & & Depression $\geq 10$ & $3.96 \pm 1.97$ & \\
\hline Anxiety $<8$ & $3.08 \pm 1.31$ & & Depression $<10$ & $3.14 \pm 1.70$ & \\
\hline Avoidance & & \multirow{3}{*}{0.398} & Avoidance & & \multirow{3}{*}{0.318} \\
\hline Anxiety $\geq 8$ & $5.71 \pm 1.17$ & & Depression $\geq 10$ & $5.76 \pm 1.16$ & \\
\hline Anxiety $<8$ & $5.50 \pm 0.52$ & & Depression $<10$ & $5.42 \pm 0.64$ & \\
\hline Touch & & \multirow{3}{*}{0.356} & Touch & & \multirow{3}{*}{0.980} \\
\hline Anxiety $\geq 8$ & $3.96 \pm 2.30$ & & Depression $\geq 10$ & $3.76 \pm 2.20$ & \\
\hline Anxiety $<8$ & $3.25 \pm 2.17$ & & Depression $<10$ & $3.78 \pm 2.48$ & \\
\hline Premature Ejaculation & & \multirow{3}{*}{0.060} & Premature Ejaculation & & \multirow{3}{*}{0.072} \\
\hline Anxiety $\geq 8$ & $5.31 \pm 1.59$ & & Depression $\geq 10$ & $5.33 \pm 1.68$ & \\
\hline Anxiety $<8$ & $4.25 \pm 1.71$ & & Depression $<10$ & $4.35 \pm 1.49$ & \\
\hline Erectile Dysfunction & & \multirow{3}{*}{0.371} & Erectile Dysfunction & & \multirow{3}{*}{0.253} \\
\hline Anxiety $\geq 8$ & $6.09 \pm 1.14$ & & Depression $\geq 10$ & $6.13 \pm 1.13$ & \\
\hline Anxiety $<8$ & $5.75 \pm 1.05$ & & Depression $<10$ & $5.71 \pm 1.06$ & \\
\hline
\end{tabular}

GRISS: Golombok-Rust Inventory of Sexual Satisfaction

sion and anxiety which was present in one-third of the cohort were associated with decreased QoL scales, and depression was independently associated with treatment adherence and with poor prognosis (2). Chen et al analyzed the effects of the walking exercise programme on anxiety, depression and cancer-related symptoms in patients with lung cancer and found that it is an effective intervention method for managing anxiety and depression in lung cancer (22).Similar to this study, Quist et al showed that a 6-week hospital-based supervised and structured exercise program, patients with advanced-stage lung cancer improved their physical capacity, functional capacity, anxiety level, and emotional well-being (23).In advanced lung cancer patients, poor performance status and psychological distress was found to be related with fatigue (24). So, by decreasing fatigue with exercise, both functional and psychological functions of the patients can be improved.

Table 4. The mean scores of EORTC-QLQ-C30 function scales of the patients

\section{Patient score}

Physical functioning

$57.9 \pm 24.54$

Role functioning

$71.09 \pm 31.2$

Cognitive functioning

$77.5 \pm 25.3$

Emotional functioning

$68.47 \pm 27.33$

Social functioning

$68.81 \pm 25.11$ 
Table 5. The mean EORTC-QLQ-C30 scores according to anxiety and depression levels of the patients

\begin{tabular}{|c|c|c|c|c|c|}
\hline & Patient score & $\mathbf{P}$ & & Patient score & $\mathbf{P}$ \\
\hline $\begin{array}{r}\text { Physical functioning } \\
\text { Anxiety } \geq 8 \\
\text { Anxiety }<8\end{array}$ & $\begin{array}{l}49.31 \pm 21.04 \\
80.83 \pm 17.82\end{array}$ & 0.000 & $\begin{array}{l}\text { Physical functioning } \\
\text { Depression } \geq 10 \\
\text { Depression }<10\end{array}$ & $\begin{array}{l}53.23 \pm 22.16 \\
67.92 \pm 27.15\end{array}$ & 0.064 \\
\hline $\begin{array}{r}\text { Role functioning } \\
\text { Anxiety } \geq 8 \\
\text { Anxiety }<8\end{array}$ & $\begin{array}{l}62.81 \pm 31.85 \\
93.16 \pm 14.92\end{array}$ & 0.000 & $\begin{array}{l}\text { Role functioning } \\
\text { Depression } \geq 10 \\
\text { Depression }<10\end{array}$ & $\begin{array}{l}65.86 \pm 30.17 \\
82.20 \pm 31.59\end{array}$ & 0.105 \\
\hline $\begin{array}{c}\text { Cognitive functioning } \\
\text { Anxiety } \geq 8 \\
\text { Anxiety }<8\end{array}$ & $\begin{array}{l}70.06 \pm 25.87 \\
97.33 \pm 6.22\end{array}$ & 0.000 & $\begin{array}{l}\text { Cognitive functioning } \\
\text { Depression } \geq 10 \\
\text { Depression }<10\end{array}$ & $\begin{array}{l}71.30 \pm 26.90 \\
90.64 \pm 15.51\end{array}$ & 0.005 \\
\hline $\begin{array}{c}\text { Emotional functioning } \\
\text { Anxiety } \geq 8 \\
\text { Anxiety }<8\end{array}$ & $\begin{array}{l}61.81 \pm 27.79 \\
86.25 \pm 16.38\end{array}$ & 0.001 & $\begin{array}{l}\text { Emotional functioning } \\
\text { Depression } \geq 10 \\
\text { Depression }<10\end{array}$ & $\begin{array}{l}58.93 \pm 26.92 \\
88.92 \pm 13.89\end{array}$ & 0.000 \\
\hline $\begin{array}{r}\text { Social functioning } \\
\text { Anxiety } \geq 8 \\
\text { Anxiety }<8\end{array}$ & $\begin{array}{l}61.75 \pm 24.41 \\
87.66 \pm 15.91\end{array}$ & 0.001 & $\begin{array}{l}\text { Social functioning } \\
\text { Depression } \geq 10 \\
\text { Depression }<10\end{array}$ & $\begin{array}{l}61.93 \pm 24.36 \\
83.57 \pm 20.46\end{array}$ & 0.006 \\
\hline $\begin{array}{r}\text { Global quality of life } \\
\text { Anxiety } \geq 8 \\
\text { Anxiety }<8\end{array}$ & $\begin{array}{l}55.09 \pm 28.10 \\
50.83 \pm 34.20\end{array}$ & 0.675 & $\begin{array}{l}\text { Global quality of life } \\
\text { Depression } \geq 10 \\
\text { Depression }<10\end{array}$ & $\begin{array}{l}53.79 \pm 29.32 \\
54.21 \pm 31.11\end{array}$ & 0.966 \\
\hline
\end{tabular}

Our study, although conducted in a limited number of patients, emphasized that depression and anxiety rates of metastatic LC patients were very high. Symptoms of depression and anxiety are frequently seen after the diagnosis of LC and may deteriorate both health-related QoL and survival $(25,26)$. Additionally, diagnosis of this type of mostly incurable cancer increases their psychological distress including sexual dysfunction. Therefore, we have to deal with all problems of metastatic lung cancer patients while treating them with chemotherapeutics. Their state of anxiety, depression and sexual satisfaction needs to be assessed as frequently as possible. When there was significant depression or anxiety, we have to refer them for psychosocial treatment in order to improve their quality of life.

\section{Conflict of Interest: None}

\section{References}

1. Sarna L, Brown JK, Cooley ME, et al. Quality of life and meaning of illness of women with lung cancer. Oncol Nurs Forum 2005;32:E9-19

2. Arrieta $\mathrm{O}$, Angulo LP, Núñez-Valencia $\mathrm{C}$, et al. Association of depression and anxiety on quality of life, treatment adherence, and prognosis in patients with advanced non-small cell lung cancer. Ann Surg Oncol 2013;20:1941-8

3. Delibegovic A, Sinanovic O. The influence of palliative care on the level of anxiety and depression in lung cancer patients. Med Arch 2013;67:263-5

4. Lindau ST, Surawska H, Paice J, Baron SR. Communication about sexuality and intimacy in couples affected by lung cancer and their clinical-care providers. Psychooncology 2011;20:179-85

5. Reese JB, Shelby RA, Abernethy AP. Sexual concerns in lung cancer patients: an examination of predictors and moderating effects of age and gender. Support Care Cancer 2011;19:161-5

6. Schwartz S, Plawecki HM. Consequences of chemotherapy on the sexuality of patients with lung cancer. Clin J Oncol Nurs 2002;6:212-6

7. Shell JA, Carolan M, Zhang Y, Meneses KD. The longitudinal effects of cancer treatment on sexuality in 
individuals with lung cancer. Oncol Nurs Forum 2008;35:73-9

8. Ilonen IK, Räsänen JV, Knuuttila A, et al. Quality of life following lobectomy or bilobectomy for nonsmallcell lung cancer, a two-year prospective follow-up study. Lung Cancer 2010;70:347-51

9. Dancey J, Shepherd FA, Gralla RJ, Kim YS. Quality of life assessment of second-line docetaxel versus best supportive care in patients with non-small-celllung cancer previously treated with platinum-based chemoherapy: results of a prospective, randomized phase III trial.Lung Cancer 2004;43:183-94

10. Tegin B. Cognitive disorders in depression: A review according to Beck Model. Ankara 1980. Psychol J 1987;6:116-23 (in Turkish)

11. Hisli N. A study on the validity of the Beck Depression Inventory. Psychol J 1988;22:118-26 (in Turkish).

12. Beck AT, Guthy D, Steer RA, Ball R. Interna con-1 sistencies of the original and revised Beck Depression Inventory. J Clin Psychol 1984;40:1365-7

13. Rust J, Golombok S. The GRISS: a psychometric instrument for the assessment of sexual dysfunction. Arch Sex Behav 1986;15:157-165

14. Tuğrul C, Öztan N, Kabakçı E. Golombok - Rust Cinsel Doyum Ölçeği'nin standardizasyon çalışması. Türk Psikiyatri Dergisi 1993; 4:83-8

15. Aaronson NK, Ahmedzai S, Bergman B, et al. The European Organization for Research and Treatment of Cancer QLQ-c30: a quality of life instrument for use in international clinical trials in oncology. J Natl Cancer Inst 1993;85(5):365-76

16. Fayers $\mathrm{P}$, Aaronson N, Bjordal K, Groenvold $\mathrm{M}$, Curran D, Bottomley A (2001). EORTC QLQ-C30 Scoring Manual, In third edition ed 2001

17. Kramer JA. Use of the Hospital Anxiety and Depression Scale (HADS) in the assessment of depression in patients with inoperable lung cancer. Palliat Med 1999;13:353-4

18. Cataldo JK, Brodsky JL. Lung cancer stigma, anxiety, depression and symptom severity. Oncology 2013;85:33-40

19. Haun MW, Sklenarova $H$, Villalobos $M$, et al. Depression, anxiety and disease-related distress in couples affected by advanced lung cancer. Lung Cancer 2014;86:274-80
20. Lo C, Zimmermann C, Rydall A, et al. Longitudinal study of depressive symptoms in patients with metastatic gastrointestinal and lung cancer. J Clin Oncol. 2010;28:3084-9

21. Nipp RD, Greer JA, El-Jawahri A, et al. Age and Gender Moderate the Impact of Early Palliative Care in Metastatic Non-Small

Cancer. Oncologist. 2016;21:119-26

22. Chen HM, Tsai CM, Wu YC, Lin KC, Lin CC. Randomised controlled trial on the effectiveness of home-based walking exercise on anxiety, depression and cancer-related symptoms in patients with lung cancer. Br J Cancer 2015;112:43845

23. Quist M, Adamsen L, Rørth M, Laursen JH , Christensen KB, Langer SW. The Impact of a Multidimensional Exercise Intervention on Physical and Functional Capacity, Anxiety, and Depression in Patients With Advanced-Stage Lung Cancer Undergoing Chemotherapy. Integr Cancer Ther 2015;14:341-9

24.Brown DJ, McMillan DC, Milroy R. The correlation between fatigue, physical function, the systemic inflammatory response, and psychological distress in patients with advanced lung cancer. Cancer 2005; 103:377-82

25.Songür N, Erenci G, Özdilekcan C, Karşıgil H, Akkoç Z. Depression Rates Before Diagnosis and After Treatment in Patients With Advanced Lung Cancer. Turkish Respiratory Journal 2004;5:073-081

26. Suna N, Yalcın B, Ekinci AS, et al. İkinci basamak kemoterapi alan veya almayan ileri evre küçük hücreli dışı akciğer kanserli hastalarda yaşam kalitesi değerlendirilmesi. Acta Oncol Tur 2015;48:53-62 